\title{
Letter to the editor: Importance of serum bactericidal activity for estimating the breadth of protection for new meningococcal vaccines
}

AS Anderson ${ }^{1}$, JJ Eiden ${ }^{1}$, JL Perez ${ }^{2}$, P Balmer ${ }^{2}$, LJ York ${ }^{3}$, KU Jansen ${ }^{1}$

1. Pfizer Vaccine Research and Development, Pearl River, New York, United States

2. Pfizer Vaccine Research and Development, Collegeville, Pennsylvania, United States

3. Pfizer Medical and Scientific Affairs, Collegeville, Pennsylvania, United States

Correspondence: Annaliesa S. Anderson (annaliesa.anderson@pfizer.com)

Citation style for this article:

Anderson AS, Eiden JJ, Perez JL, Balmer P, York LJ, Jansen KU. Letter to the editor: Importance of serum bactericidal activity for estimating the breadth of protection for new meningococcal vaccines. Euro Surveill. 2016;21(15):pii=30191. DOI: http://dx.doi.org/10.2807/1560-7917.ES.2016.21.15.30191

Article submitted on 16 March 2016 / accepted on 08 April 2016 / published on 14 April 2016

To the editor: Brehony and colleagues [1] recently reported their investigation of six Neisseria meningitidis serogroup $\mathrm{B}(\mathrm{NmB})$ vaccines by deducing the prevalence of the vaccine components in isolates represented in publicly accessible sequence repositories of $\mathrm{NmB}$. Based on the frequency of exact match of deduced peptide sequences in the databases to at least one component of each vaccine, and by assessing published data, the authors estimated the breadth of strain coverage. Their findings led them to conclude that meningococcal vaccines with multiple antigens would provide greater breadth of coverage against meningococcal disease. However, their evaluation did not incorporate important information about the diversity of factor $\mathrm{H}$ binding protein ( $\mathrm{fHBP}$ ) variants and the demonstration of protective immune responses against antigenically diverse $\mathrm{MnB}$ invasive disease strains following vaccination with Trumenba. Consequently, the authors' analysis underestimates the potential for vaccine benefit provided by this licensed vaccine. We provide here a description of published data, including results that use the recognised correlate of protection for NmB, serum bactericidal activity measured using serum bactericidal assays performed with human complement (hSBA) [2,3]. This correlation was first validated in large clinical studies using outer membrane vesicle (OMV) vaccines that confer protection via induction of immune response directed against the PorA antigen of $\mathrm{NmB}$ [4]. Protection is essentially restricted to strains expressing the matched PorA sequence in the vaccine [5], thus the approach used by the authors to estimate vaccine strain coverage is appropriate for PorA based vaccines, such as the experimental vaccine NonaMen, as described.

However, this approach is not sufficient for estimation of vaccine protection for Trumenba, which was licensed in the United States in 2014. The vaccine is composed of two lipidated, recombinant fHBPs: 3.45 (subfamily $A:$ A05) and 1.55 (subfamily B: B01). Individual strains of $\mathrm{NmB}$ express a single fHBP variant which may be either subfamily A or subfamily B. Preclinical studies demonstrated that hSBA responses induced by a single fHBP were greater against invasive disease strains expressing fHBP of the same subfamily than against those expressing a variant of the other subfamily, and a vaccine that contained one lipidated protein from each subfamily generated antibodies that killed $\mathrm{MnB}$ strains regardless of the $\mathrm{FHBP}$ variant they expressed $[6,7]$. In clinical studies in subjects aged 18 months to 62 years, Trumenba (and an earlier formulation of the vaccine) induced hSBA against invasive disease strains that expressed fHBP variants heterologous to the vaccine antigen and represented the antigenic diversity of fHBP [8-14]. These data demonstrate that the bactericidal response elicited by this bivalent single antigen vaccine is directed against a broad and diverse range of fHBP expressed by $\mathrm{NmB}$ and is not limited to $\mathrm{NmB}$ strains that express fHBP homologous (an exact match) to the vaccine antigens. The hSBA responses were also observed not to be restricted to $\mathrm{NmB}$ strains within specific clonal complexes. These data demonstrate the importance of inclusion of hSBA results for assessment of the potential breadth of protection provided by $\mathrm{NmB}$ vaccines.

In summary, published data using hSBA, the correlate of protection against $N$. meningitidis, indicate that the breadth of protection for Trumenba is broader than can be extrapolated from reference only to the distribution of the matched vaccine antigens present in disease-causing strains of $\mathrm{NmB}$. While we await direct, post-licensure assessments of vaccine effectiveness against clinical disease, the estimation of potential vaccine benefit should consider results of hSBA assays performed with $\mathrm{NmB}$ test strains that express antigens 
heterologous to vaccine components, rather than reliance only on exact antigenic sequence matches and assays that do not measure bactericidal activity.

\section{Acknowledgements}

This letter was funded by Pfizer Inc. Additional editorial support was provided by Jill E. Kolesar, PhD, of Complete Healthcare Communications, LLC, and funded by Pfizer Inc.

\section{Conflict of interest}

ASA, JJE, JLP, PB, LJY, and KUJ are all employees of Pfizer Inc.

\section{Authors' contributions}

All authors were involved in drafting or editing the manuscript.

\section{References}

1. Brehony C, Hill DM, Lucidarme J, Borrow R, Maiden MC. Meningococcal vaccine antigen diversity in global databases. Euro Surveill. 2015;20(49):30084. DOI: 10.2807/1560-7917. ES.2015.20.49.30084 PMID: 26676305

2. Borrow R, Carlone GM, Rosenstein N, Blake M, Feavers I, Martin D, et al. Neisseria meningitidis group B correlates of protection and assay standardization--international meeting report Emory University, Atlanta, Georgia, United States, 16-17 March 2005. Vaccine. 2006;24(24):5093-107. DOI: 10.1016/j. vaccine.2006.03.091 PMID: 16838413

3. Frasch CE, Borrow R, Donnelly J. Bactericidal antibody is the immunologic surrogate of protection against meningococcal disease.Vaccine. 2009;27(Suppl 2):B112-6. DOI: 10.1016/j. vaccine.2009.04.065 PMID: 19464093

4. Tan LK, Carlone GM, Borrow R. Advances in the development of vaccines against Neisseria meningitidis.N Engl J Med. 2010;362(16):1511-20. DOI: 10.1056/NEJMra0906357 PMID 20410516

5. Holst J, Martin D, Arnold R, Huergo CC, Oster P, O'Hallahan J, et al. Properties and clinical performance of vaccines containing outer membrane vesicles from Neisseria meningitidis. Vaccine. 2009;27(Suppl 2):B3-12. DOI: 10.1016/j.vaccine.2009.04.071 PMID: 19481313

6. Fletcher LD, Bernfield L, Barniak V, Farley JE, Howell A, Knauf $M$, et al. Vaccine potential of the Neisseria meningitidis 2086 lipoprotein. Infect Immun. 2004;72(4):2088-100. DOI: 10.1128/ IAI.72.4.2088-2100.2004 PMID: 15039331

7. Jiang HQ, Hoiseth SK, Harris SL, McNeil LK, Zhu D, Tan C, et al. Broad vaccine coverage predicted for a bivalent recombinant factor $\mathrm{H}$ binding protein based vaccine to prevent serogroup $\mathrm{B}$ meningococcal disease. Vaccine. 2010;28(37):6086-93. DOI: 10.1016/j.vaccine.2010.06.083 PMID: 20619376

8. Harris SL, Zhu D, Murphy E, McNeil LK, Wang X, Mayer LW, et al. Preclinical evidence for the potential of a bivalent fHBP vaccine to prevent Neisseria meningitidis Serogroup C Disease. Hum Vaccin. 2011;7(sup1) Suppl;68-74. DOI: 10.4161/ hv.7.0.14564 PMID: 21245657

9. Marshall HS, Richmond PC, Nissen MD, Jiang Q, Anderson AS, Jansen KU, et al. Safety and immunogenicity of a meningococcal B bivalent rLP2086 vaccine in healthy toddlers aged 18-36 months: a phase 1 randomized-controlled clinical trial. Pediatr Infect Dis J. 2012;31(10):1061-8.PMID: 22718089

10. Marshall HS, Richmond PC, Nissen MD, Wouters A, Baber J, Jiang $Q$, et al. A phase 2 open-label safety and immunogenicity study of a meningococcal B bivalent rLP2086 vaccine in healthy adults. Vaccine. 2013;31(12):1569-75. DOI: 10.1016/j. vaccine.2013.01.021 PMID: 23352429

11. Nissen MD, Marshall HS, Richmond PC, Jiang Q, Harris SL, Jones TR, et al. A randomized, controlled, phase $1 / 2$ trial of a Neisseria meningitidis serogroup B bivalent rLP2086 vaccine in healthy children and adolescents. Pediatr Infect Dis J. 2013;32(4):364-71. DOI: 10.1097/INF.obo13e31827bod24 PMID: 23114369

12. Reiner DM, Bhuyan P, Eiden JJ, Ginis J, Harris S, Jansen $\mathrm{KU}$, et al. Immunogenicity, safety, and tolerability of the meningococcal serogroup B bivalent rLP2086 vaccine in adult laboratory workers. Vaccine. 2016;34(6):809-13. DOI: 10.1016/j. vaccine.2015.12.016 PMID: 26707218

13. 2001 Study Investigators, Richmond PC, Marshall HS, Nissen MD, Jiang Q, Jansen KU, Garcés-Sánchez M, et al. . Safety, immunogenicity, and tolerability of meningococcal serogroup $B$ bivalent recombinant lipoprotein 2086 vaccine in healthy adolescents: a randomised, single-blind, placebo-controlled, phase 2 trial.Lancet Infect Dis. 2012;12(8):597-607. DOI: 10.1016/S1473-3099(12)70087-7 PMID: 22569484

14. Vesikari T, Østergaard L, Diez-Domingo J, Wysocki J, Flodmark CE, Beeslaar J, et al. Meningococcal Serogroup B Bivalent rLP2086 Vaccine Elicits Broad and Robust Serum Bactericidal Responses in Healthy Adolescents. J Pediatric Infect Dis Soc. 2015;piv039. DOI: 10.1093/jpids/pivo39 PMID: 26407272

\section{License and copyright}

This is an open-access article distributed under the terms of the Creative Commons Attribution (CC BY 4.0) Licence. You may share and adapt the material, but must give appropriate credit to the source, provide a link to the licence, and indicate if changes were made.

This article is copyright of the authors, 2016. 